\title{
Article \\ Surgical Treatment of Diabetic Foot Ulcers Complicated by Osteomyelitis with Gentamicin-Loaded Calcium Sulphate-Hydroxyapatite Biocomposite
}

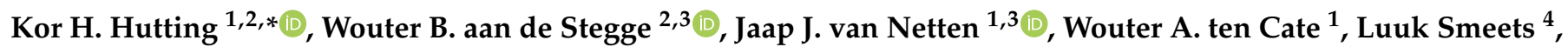 \\ Gijs M. J. M. Welten ${ }^{5}$, Dick M. Scharn ${ }^{6}$, Jean-Paul P. M. de Vries ${ }^{2}$ and Jeff G. van Baal ${ }^{1,7}$ \\ 1 Department of Surgery, Hospital Group Twente, Zilvermeeuw 1, \\ 7609 PP Almelo, Overijssel, The Netherlands; j.j.vannetten@amsterdamumc.nl (J.J.v.N.); \\ W.tCate@zgt.nl (W.A.t.C.); j.vbaal@zgt.nl (J.G.v.B.) \\ 2 Division of Vascular Surgery, Department of Surgery, University Medical Center Groningen, Hanzeplein 1, \\ 9713 GZ Groningen, Groningen, The Netherlands; w.b.aandestegge@amsterdamumc.nl (W.B.a.d.S.); \\ j.p.p.m.de.vries@umcg.nl (J.-P.P.M.d.V.) \\ 3 Department of Rehabilitation, University of Amsterdam, Amsterdam UMC, Amsterdam Movement Sciences, \\ Meibergdreef 9, 1105 AZ Amsterdam, Noord-Holland, The Netherlands \\ 4 Department of Surgery, Rijnstate Hospital, Wagnerlaan 55, 6815 AD Arnhem, Gelderland, The Netherlands; \\ LSmeets@rijnstate.nl \\ 5 Department of Surgery, Franciscus Gasthuis \& Vlietland, Kleiweg 500, \\ 3045 PM Rotterdam, Zuid-Holland, The Netherlands; g.welten@franciscus.nl \\ check for \\ updates \\ Citation: Hutting, K.H.; aan de \\ 6 Department of Surgery, Slingeland Hospital, Kruisbergseweg 25, \\ 7009 BL Doetinchem, Gelderland, The Netherlands; d.scharn@slingeland.nl \\ 7 Welsh Wound Innovation Centre, Rhodfa Marics, Ynysmaerdy, Pontyclun CF72 8UX, Wales, UK \\ * Correspondence: Hutting.kor@gmail.com; Tel.: +31-6-2303-1469
} Stegge, W.B.; van Netten, J.J.; ten Cate, W.A.; Smeets, L.; Welten, G.M.J.M.; Scharn, D.M.; de Vries, J.-P.M.; van Baal, J.G. Surgical Treatment of Diabetic Foot Ulcers Complicated by Osteomyelitis with Gentamicin-Loaded Calcium Sulphate-Hydroxyapatite Biocomposite. J. Clin. Med. 2021, 10, 371. https://doi.org/10.3390/ jcm10020371

Received: 6 December 2020

Accepted: 15 January 2021

Published: 19 January 2021

Publisher's Note: MDPI stays neutral with regard to jurisdictional claims in published maps and institutional affiliations.

Copyright: (C) 2021 by the authors Licensee MDPI, Basel, Switzerland. This article is an open access article distributed under the terms and conditions of the Creative Commons Attribution (CC BY) license (https:/ / creativecommons.org/licenses/by/ $4.0 /)$.
Abstract: Diabetic foot ulcers, complicated by osteomyelitis, can be treated by surgical resection, dead space filling with gentamicin-loaded calcium sulphate-hydroxyapatite (CaS-HA) biocomposite, and closure of soft tissues and skin. To assess the feasibility of this treatment regimen, we conducted a multicenter retrospective cohort study of patients after failed conventional treatments. From 13 hospitals we included 64 patients with forefoot $(n=41(64 \%))$, midfoot $(n=14(22 \%))$, or hindfoot $(n=9(14 \%))$ ulcers complicated by osteomyelitis. Median follow-up was 43 (interquartile range, 20-61) weeks. We observed wound healing in 54 patients (84\%) and treatment success (wound healing without ulcer recurrence) in 42 patients $(66 \%)$. Treatment failures (no wound healing or ulcer recurrence) led to minor amputations in four patients $(6 \%)$ and major amputations in seven patients $(11 \%)$. Factors associated with treatment failures in univariable Cox regression analysis were gentamicin-resistant osteomyelitis (hazard ratio (HR), 3.847; 95\%-confidence interval (CI), 1.065-13.899), hindfoot ulcers (HR, 3.624; 95\%-CI, 1.187-11.060) and surgical procedures with gentamicin-loaded CaS-HA biocomposite that involved minor amputations (HR, 3.965; 95\%-CI, 1.608-9.777). In this study of patients with diabetic foot ulcers, complicated by osteomyelitis, surgical treatment with gentamicin-loaded CaS-HA biocomposite was feasible and successful in $66 \%$ of patients. A prospective trial of this treatment regimen, based on a uniform treatment protocol, is required.

Keywords: diabetes mellitus; foot ulcers; foot infections; gentamicin-loaded calcium sulphatehydroxyapatite biocomposite; osteomyelitis; surgery

\section{Introduction}

In people with diabetes mellitus, foot ulcers are a major complication, with a lifetime prevalence of $19-34 \%$ [1]. An estimated 18.6 million people are currently affected by diabetic foot ulcers [2]. Approximately $60 \%$ of diabetic foot ulcers are infected at presentation, and $40 \%$ of the noninfected diabetic foot ulcers become infected before healing [3,4]. Infected 
diabetic foot ulcers increase morbidity and are the most common cause of diabetes-related hospitalizations and lower extremity amputations [5,6]. Approximately $20 \%$ of infected diabetic foot ulcers are complicated by osteomyelitis, which is defined as infection of the bone with involvement of bone marrow [7,8]. In patients with diabetic foot ulcers complicated by osteomyelitis (DFO), ulcer healing is impaired and the amputation risk is increased [9-11].

Current treatment regimens for patients with DFO consist of standard foot ulcer management (offloading, restoration of tissue perfusion, local ulcer care with debridement and wound dressings), optimization of glycemic control with antibiotic therapy, and, when required, surgical resection of necrotic and infected soft tissues and necrotic bone [12-15]. These treatments may result in wound healing in $78 \%$ to $86 \%$ of patients [16-18]. However, surgical resection requires minor amputations (distal to the ankle) in up to $40 \%$ of patients. In $6 \%$ to $23 \%$ of these patients, successive minor amputations on more proximal levels are required due to treatment failures, and up to $9 \%$ of these patients end up undergoing a major amputation [16-19].

Several new treatment regimens are being developed to improve outcomes, with the aim of reducing amputation rates and preserving patient mobility. Surgical resection of macroscopically necrotic and infected soft tissues and necrotic bone with subsequent filling of the resultant void (the "dead space") using a calcium sulphate-hydroxyapatite (CaS-HA) biocomposite bone graft substitute loaded with gentamicin, could be a promising new treatment regimen $[20,21]$. This treatment regimen requires surgical closure by primary closure or reconstructive techniques to prevent CaS-HA biocomposite leakage and to cover exposed bone [22-24]. Therefore, surgical procedures in this treatment regimen are often performed in one stage. Local release of gentamicin from the CaS-HA biocomposite leads to a high tissue concentration of gentamicin for several weeks that eradicates pathogens $[25,26]$. Furthermore, the CaS-HA biocomposite functions as an osteoconductive scaffold that supports bone augmentation and prevents bone resorption [20,22,27].

Promising results have been reported on this treatment regimen for DFO in three previous retrospective studies and one case report [23,24,28,29]. Uncomplicated wound healing is reported in $80 \%$ to $100 \%$ of these patients, and amputations are only reported after treatment failures $[23,24,28,29]$. However, these previous studies all have a retrospective design and lack details of treatments (e.g., antibiotic therapy or offloading) and other outcomes than postoperative wound healing (e.g., ulcer recurrence) $[23,24,28,29]$. Therefore, additional investigation is required to assess the feasibility of this treatment regimen.

Currently, the use of gentamicin-loaded CaS-HA biocomposite is not incorporated in (inter)national guidelines for the treatment of DFO [14,30,31]. However, several hospitals in the Netherlands have used gentamicin-loaded CaS-HA biocomposite to treat patients with DFO after failed conventional treatments. We conducted a multicenter, retrospective cohort study to investigate the feasibility of this treatment regimen for DFO after failed conventional treatments.

\section{Experimental Section}

We conducted a retrospective multicenter cohort study of patients treated between February 2017 and June 2019. Retrospective data collection was completed in December 2019. Dutch hospitals in which surgical treatments of DFO with gentamicin-loaded CaSHA biocomposite were performed were contacted. The physicians (vascular surgeons and/or trauma surgeons) who performed the surgical treatments were assigned as local investigators. Patients provided written informed consent for data collection, analysis and storage. We performed all study procedures according to the Declaration of Helsinki and the Dutch Personal Data Protection Act. The Medical Ethics Committee Twente ruled this study exempt from formal ethical approval because of the retrospective observational design (METC Twente project K18-33).

We included patients with diabetes mellitus with one or more foot ulcers complicated by suspected or confirmed osteomyelitis who underwent a surgical procedure with 
gentamicin-loaded CaS-HA biocomposite (Cerament $\mathrm{G}^{\mathrm{TM}}$; BoneSupport, Lund, Sweden). We defined a foot ulcer as a discontinuation of the skin that minimally includes the epidermis and part of the dermis [8]. In accordance with the International Working Group on the Diabetic Foot (IWGDF) guidelines and the Dutch national guidelines, suspected osteomyelitis was defined as the presence of suggestive clinical signs (e.g., positive probe-to-bone test, exposed bone and/or intraosseous pus at intervention), elevated serum inflammatory markers and suggestive findings of osteomyelitis on imaging assessment (X-ray imaging, computed tomography, magnetic resonance imaging or radionuclide imaging) [14,30,32]. Confirmed osteomyelitis was defined as bone samples with cultures positive for microbiological pathogens $[14,30,32]$.

Prerequisites for performing surgical procedures with gentamicin-loaded CaS-HA biocomposite were that the soft tissues and skin around the ulcer were adequate for closure of surgical wounds by primary closure or by reconstructive techniques. All patients were treated with gentamicin-loaded CaS-HA biocomposite as a last resort after conventional treatments of DFO failed. Failed conventional treatment was defined as a persistent foot ulcer with unresolved osteomyelitis after prolonged antibiotic therapy ( $>6$ weeks [14]) or a persistent wound with unresolved osteomyelitis after surgical resection of DFO or minor amputation with adjuvant antibiotic therapy (approximately 1 week [14]). Minor amputation was defined as any resection through or distal to the ankle, in accordance with the IWGDF definition [8]. Osteomyelitis was in these cases diagnosed as described above. Only the first procedure was included if patients underwent multiple treatments with gentamicin-loaded CaS-HA biocomposite.

We excluded patients with severe chronic limb ischemia, irrespective of preoperative revascularization, because of the low probability of postoperative wound healing [33]. Severe chronic limb ischemia was defined in accordance with the wound, ischemia and foot infection classification as an ankle-brachial index $\leq 0.39$, an ankle systolic pressure $<50 \mathrm{mmHg}$, a systolic toe pressure $<30 \mathrm{mmHg}$ or a transcutaneous oxygen pressure $<30 \mathrm{mmHg}$ [33].

When this study was conducted, no uniform treatment protocol existed for the surgical treatment of DFO with gentamicin-loaded CaS-HA biocomposite. The surgical procedures with gentamicin-loaded CaS-HA biocomposite generally consisted of the following steps: After excision of one or more foot ulcers, macroscopic necrotic bone and necrotic and infected soft tissues were resected (Figure 1A). In most cases, surgeons obtained one or more bone samples for examination of microbiological pathogens. The remaining dead space was irrigated with saline solution and filled with CaS-HA biocomposite loaded with gentamicin $(17.5 \mathrm{mg} / \mathrm{mL}$ ) via injection or as pellets (Figure 1B,C). Guidance using x-ray imaging was used at the surgeons' discretion.
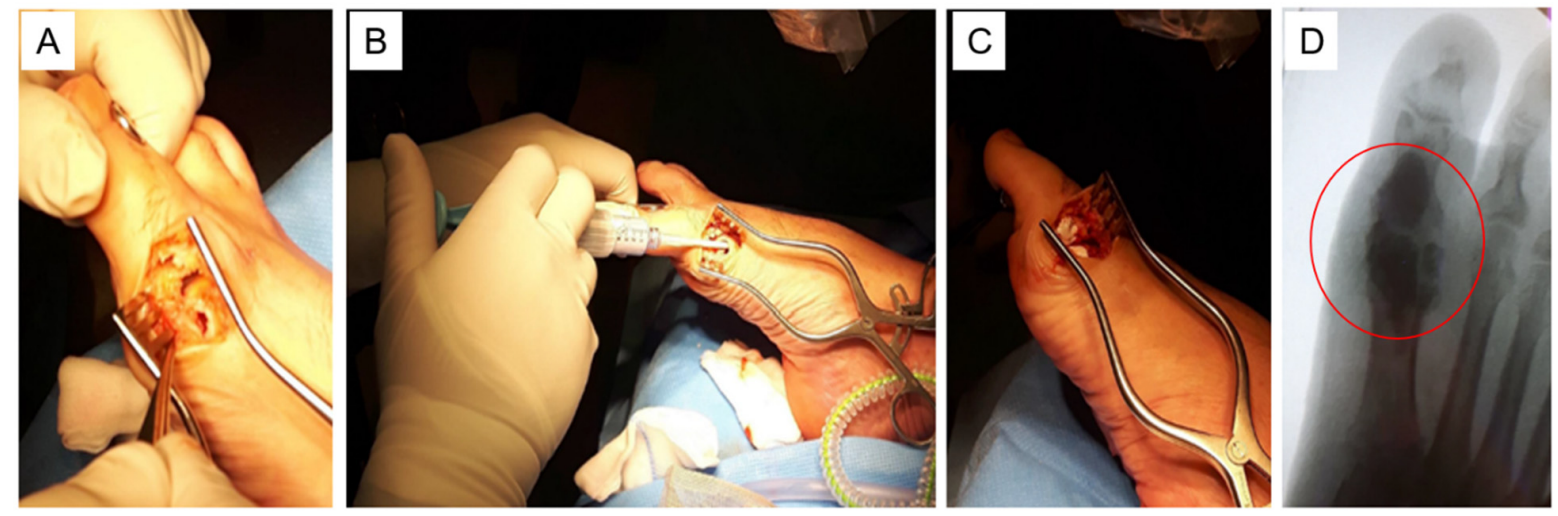

Figure 1. Surgical treatment with gentamicin-loaded calcium sulphate-hydroxyapatite (CaS-HA) biocomposite of a diabetic foot ulcer, complicated by osteomyelitis, at the medial aspect of the first metatarsophalangeal joint. (A) After surgical excision of the foot ulcer, macroscopic necrotic bone and necrotic and infected soft tissues are resected. (B) The dead space is irrigated with saline solution, and gentamicin-loaded CaS-HA biocomposite is injected. (C) The dead space is filled with gentamicin-loaded CaS-HA biocomposite. (D) In this dorsal-plantar x-ray image of the foot, the gentamicin-loaded CaS-HA biocomposite is visible as a density in the distal part of the metatarsal and the proximal phalanx (encircled). 
After the dead space was filled with gentamicin-loaded CaS-HA biocomposite, surgical wounds were closed by primary closure or reconstructive techniques (e.g., local transposition flaps). In certain patients with forefoot or midfoot DFO, complete resection of necrotic bone as part of the surgical procedure with gentamicin-loaded CaS-HA biocomposite resulted in a transmetatarsal amputation. These amputations were performed on a level as distally as possible, with the aim of preventing subsequent extensive proximal amputations.

After resection, the intramedullary canals of the residual metatarsals were filled with gentamicin-loaded CaS-HA biocomposite, followed by surgical closure of the amputation wounds. Temporary or definitive fixation (e.g., external fixation or Kirschner wires) methods were also required in certain patients because of biomechanical instability after bone resection. After resection of a joint, the residual dead space was filled with gentamicinloaded CaS-HA biocomposite to create a semi-rigid or rigid arthrodesis, irrespective of fixation methods used.

Decisions regarding postoperative antibiotic therapy were made independently by the treating physicians in the absence of a uniform treatment protocol. In general, postoperative antibiotic therapy was only administered to patients with extensive DFO in whom adequate surgical resection of all necrotic and infected tissues was difficult. Postoperative offloading was advised in all patients until postoperative wound healing was observed. Again, lack of a uniform treatment protocol resulted in individual decisions of treating physicians regarding the use of offloading devices and postoperative wound care (e.g., bandages).

In the participating centers, local investigators selected patients according to the inclusion criteria and retrospectively collected data from electronic health record systems which were registered in a secured database (OpenClinica LLC, Version 3.13, Waltham, MA, USA). Data regarding demographics, comorbidities, index ulcers and affected feet were collected. We defined the index ulcer as the clinically most important foot ulcer with the clearest association to the underlying osteomyelitis as judged clinically and based on imaging findings. Index ulcers located around the metatarsals, the phalanges and associated soft tissues were classified as "forefoot index ulcers", index ulcers located around the cuboid, navicular, cuneiform bones and associated soft tissues as "midfoot index ulcers," and index ulcers around the talus, calcaneum and associated soft tissues as "hindfoot index ulcers" [8]. Additionally, we classified index ulcers according to the "Site, Ischemia, Neuropathy, Bacterial infection, Area, Depth" (SINBAD) classification [34].

We collected data of loss of protective sensation and deformities of the affected foot. Loss of protective sensation was defined as absence of pressure sensation of a 10-g monofilament [13]. We classified deformities as mild (pes cavus, hallux valgus, hallux limitus or hammer toes), moderate (hallux rigidus, claw toes or prominent metatarsal heads) or severe (Charcot neuroarthropathy-related deformity, previous ankle arthrodesis or previous partial calcanectomy) [35]. The deformity graded most severe determined the classification [35]. We also registered previous contralateral major amputations (defined as any resection proximal to the ankle in correspondence with the IWGDF definition) and previous ipsilateral minor amputations [8,35]. Moreover, we collected data regarding the surgical procedures and postoperative treatments. Furthermore, we collected data of the microbiological culture results of intraoperatively obtained bone samples, including gentamicin-resistance of pathogens which was investigated using the minimal inhibitory concentration breakpoints of the European Committee on Antimicrobial Sensitivity Testing (EUCAST) (Växjö, Sweden) [36].

Follow-up was completed until minor or major amputation after the initial surgery, repeated surgical resection of DFO, death or the last-mentioned consultation in the electronic health record system. We registered data regarding postoperative wound healing, ulcer recurrence, minor and major amputations, readmissions, reoperations, functional results and adverse events, including postoperative fractures, Charcot neuroarthropathy exacerbations and deaths. Wound healing was defined as macroscopic complete epithelialization after removal of abundant callus without drainage or requirement of wound 
dressings, maintained for a minimum of 2 weeks $[8,15]$. We defined ulcer recurrence as development of an ulcer on the same location as the index ulcer after initial postoperative wound healing irrespective of the presence of (ongoing) osteomyelitis. Functional results were classified as unable to mobilize weight-bearing, able to mobilize weight-bearing with a walking aid or able to mobilize weight-bearing without a walking aid. Information was also collected regarding footwear used at the final follow-up.

As primary outcomes, we assessed postoperative wound healing and ulcer recurrence. Treatment success was defined as uncomplicated wound healing without ulcer recurrence, and treatment failure was defined as presence of a persistent wound at final follow-up or ulcer recurrence after initial postoperative wound healing. A persistent wound was defined as absence of postoperative wound healing after primary closure or closure by reconstructive techniques. As secondary outcomes, we assessed minor and major amputations and functional results at final follow-up.

Categorical data are reported as numbers of patients with corresponding percentages and continuous data as means with standard deviations (SD) or medians with interquartile ranges (IQR) when nonparametric. We compared characteristics regarding demographics, comorbidities, index ulcers, affected feet, surgical procedures and postoperative treatments between patients with treatment success, patients with treatment failure due to persistent wounds, and patients with treatment failure due to ulcer recurrence after initial postoperative wound healing. These comparisons were made using one-way analyses of variances (ANOVA) for parametric continuous data, Kruskal-Wallis tests for nonparametric continuous data and Fisher exact tests for categorical data. All tests were performed two-sided $(\alpha=0.05)$. Post hoc analyses were performed using a Bonferroni correction.

A univariable Cox regression analysis was performed to investigate associations between treatment failures and all above-mentioned characteristics. We used a KaplanMeier curve to demonstrate treatment failures, in which patients with persistent wounds were indicated as having an event at day 1. SPSS 23.0 software (IBM, Armonk, NY, USA) was used for all statistical analyses.

\section{Results}

\subsection{Patients and Procedures}

From 13 hospitals, we included 64 patients, of whom 49 (77\%) had confirmed osteomyelitis and 15 (23\%) had suspected osteomyelitis (Figure 2, Table 1). The surgical procedure with gentamicin-loaded CaS-HA biocomposite involved minor amputations in five patients $(8 \%)$ with forefoot DFO and three patients $(5 \%)$ with midfoot DFO (Table 1$)$. Details of the surgical procedures are listed in Appendix A: Table A1. 


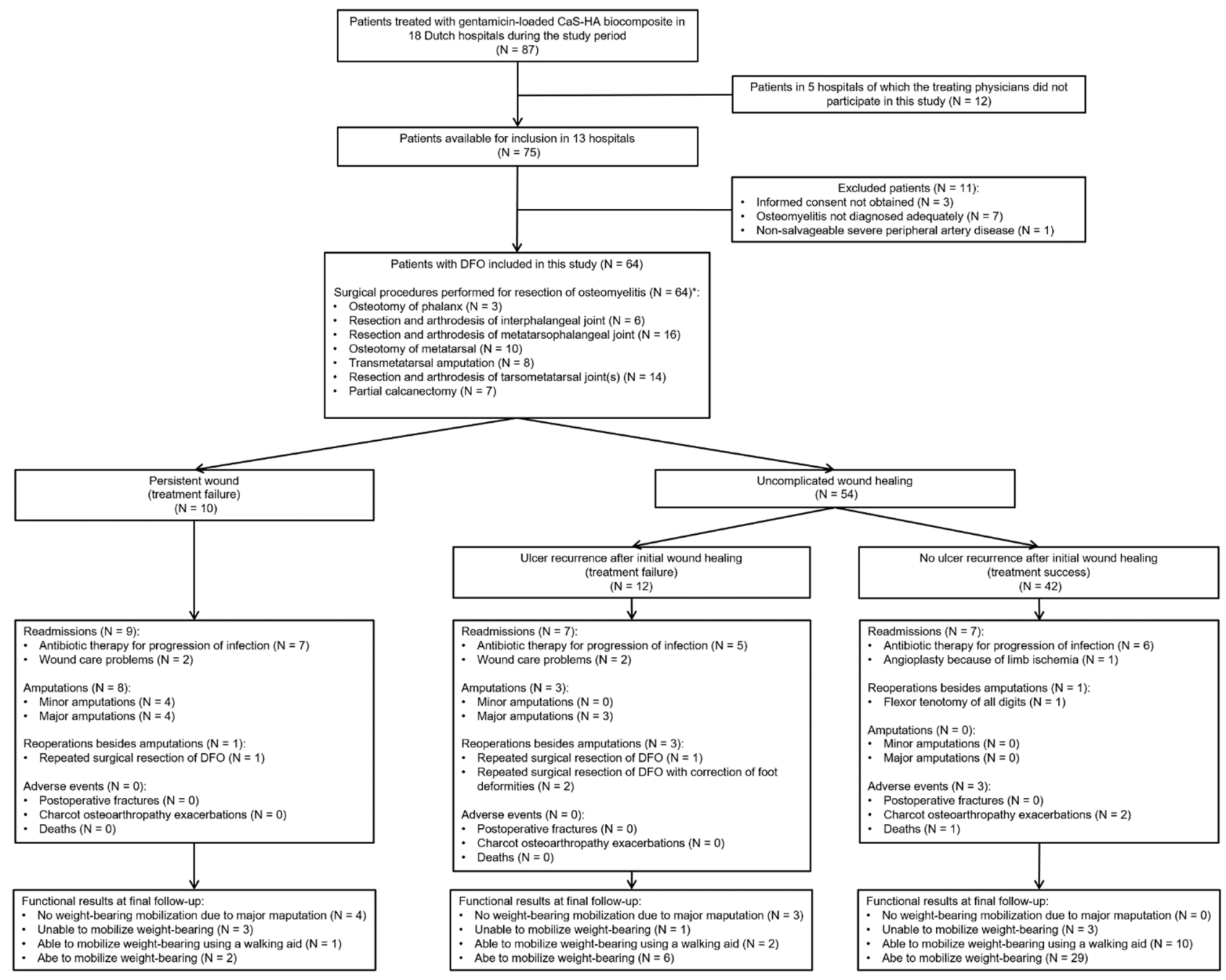

Figure 2. Study flowchart. CaS-HA: Calcium sulphate-hydroxyapatite. DFO: Diabetic foot osteomyelitis. ${ }^{*}$ Details of the surgical procedures are listed in Appendix A: Table A1.

Table 1. Study population characteristics stratified by outcome.

\begin{tabular}{|c|c|c|c|c|c|}
\hline Characteristics & All Patients & $\begin{array}{c}\text { Patients with } \\
\text { Persistent Wounds }\end{array}$ & $\begin{array}{l}\text { Patients with } \\
\text { Ulcer Recurrence }\end{array}$ & $\begin{array}{c}\text { Patients with } \\
\text { Treatment Success }\end{array}$ & $p$ Value \\
\hline & $(N=64)$ & $(n=10)$ & $(n=12)$ & $(n=42)$ & \\
\hline Follow-up in weeks & $43(20-61)$ & $14(12-27)$ & $61(23-91)$ & $44(28-61)$ & $0.001 *$ \\
\hline Male sex & $50(78)$ & $8(80)$ & $9(75)$ & $33(79)$ & $>0.99$ \\
\hline Age, years & $63 \pm 11$ & $66 \pm 9$ & $56 \pm 14$ & $64 \pm 11$ & 0.089 \\
\hline \multicolumn{6}{|c|}{ Type of diabetes mellitus } \\
\hline $\begin{array}{l}\text { Type } 1 \text { diabetes } \\
\text { Type } 2 \text { diabetes }\end{array}$ & $\begin{array}{c}5(8) \\
59(92)\end{array}$ & $\begin{array}{c}0 \\
10(100)\end{array}$ & $\begin{array}{c}2(17) \\
10(83)\end{array}$ & $\begin{array}{c}3(7) \\
39(93)\end{array}$ & 0.385 \\
\hline Diabetes duration in years & $17(13-21)$ & $17(12-22)$ & $16(10-20)$ & $17(14-22)$ & 0.359 \\
\hline Insulin treatment & $40(63)$ & $5(50)$ & $9(75)$ & $26(62)$ & 0.482 \\
\hline Heart failure & $18(28)$ & $3(30)$ & $3(25)$ & $12(29)$ & $>0.99$ \\
\hline Nephropathy & $21(33)$ & $4(40)$ & $6(50)$ & $11(26)$ & 0.262 \\
\hline Haemodialysis & $5(8)$ & 0 & $2(17)$ & $3(7)$ & 0.385 \\
\hline
\end{tabular}


Table 1. Cont.

\begin{tabular}{|c|c|c|c|c|c|}
\hline Characteristics & All Patients & $\begin{array}{c}\text { Patients with } \\
\text { Persistent Wounds }\end{array}$ & $\begin{array}{l}\text { Patients with } \\
\text { Ulcer Recurrence }\end{array}$ & $\begin{array}{c}\text { Patients with } \\
\text { Treatment Success }\end{array}$ & $p$ Value \\
\hline $\mathrm{BMI}>35 \mathrm{~kg} / \mathrm{m}^{2}$ & $5(8)$ & 0 & $1(8)$ & $4(10)$ & 0.819 \\
\hline Retinopathy & $23(36)$ & $4(40)$ & $4(33)$ & $15(36)$ & $>0.99$ \\
\hline Charcot osteoarthropathy & $18(28)$ & $0(0)$ & $7(58)$ & $11(26)$ & $0.010 * *$ \\
\hline $\begin{array}{l}\text { Loss of protective } \\
\text { sensation }\end{array}$ & $59(92)$ & $10(100)$ & $12(100)$ & $37(88)$ & 0.496 \\
\hline \multicolumn{6}{|c|}{ Limb ischemia [33] } \\
\hline - $\quad$ None & $33(52)$ & $3(30)$ & $10(84)$ & $20(48)$ & \\
\hline - $\quad$ Mild & $24(37)$ & $7(70)$ & $1(8)$ & $16(38)$ & $0.035^{* * *}$ \\
\hline - $\quad$ Moderate & $7(11)$ & 0 & $1(8)$ & $6(14)$ & \\
\hline \multicolumn{6}{|c|}{ Previous ipsilateral amputation } \\
\hline - $\quad$ None & $42(66)$ & $9(90)$ & $6(50)$ & $27(64)$ & \\
\hline - $\quad$ Lesser toe & $3(5)$ & 0 & 0 & $3(7)$ & \\
\hline - Hallux/or single ray & $9(14)$ & $1(10)$ & $4(33)$ & $4(10)$ & 0.486 \\
\hline - $\quad$ Multiple rays & $6(9)$ & 0 & $1(8)$ & $5(12)$ & \\
\hline - $\quad$ Forefoot & $4(6)$ & 0 & $1(8)$ & $3(7)$ & \\
\hline $\begin{array}{l}\text { Previous contralateral } \\
\text { major amputation }\end{array}$ & $4(6)$ & 0 & $1(8)$ & $3(7)$ & $>0.99$ \\
\hline \multicolumn{6}{|c|}{ Foot deformity } \\
\hline - $\quad$ None & $32(50)$ & $6(60)$ & $3(25)$ & $23(55)$ & \\
\hline - $\quad$ Mild & $9(14)$ & $1(10)$ & $2(17)$ & $6(14)$ & \\
\hline - $\quad$ Moderate & $8(13)$ & $3(30)$ & $1(8)$ & $4(10)$ & 0.071 \\
\hline - $\quad$ Severe & $15(23)$ & 0 & $6(50)$ & $9(21)$ & \\
\hline $\begin{array}{l}\text { Previous ulcer on index } \\
\text { ulcer location }\end{array}$ & $24(38)$ & $5(50)$ & $7(58)$ & $12(29)$ & 0.111 \\
\hline $\begin{array}{l}\text { Index ulcer duration in } \\
\text { weeks }\end{array}$ & $20(13-46)$ & $19(10-42)$ & $37(21-79)$ & $18(10-43)$ & $0.039^{\dagger}$ \\
\hline
\end{tabular}


Table 1. Cont.

\begin{tabular}{|c|c|c|c|c|c|}
\hline Characteristics & All Patients & $\begin{array}{c}\text { Patients with } \\
\text { Persistent Wounds }\end{array}$ & $\begin{array}{l}\text { Patients with } \\
\text { Ulcer Recurrence }\end{array}$ & $\begin{array}{c}\text { Patients with } \\
\text { Treatment Success }\end{array}$ & $p$ Value \\
\hline \multicolumn{6}{|c|}{ Index ulcer location } \\
\hline - $\quad$ Forefoot & $41(64)$ & $5(50)$ & $5(42)$ & $31(74)$ & \\
\hline - $\quad$ Midfoot & $14(22)$ & $2(20)$ & $5(42)$ & $7(17)$ & 0.101 \\
\hline - Hindfoot & $9(14)$ & $3(30)$ & $2(17)$ & $4(9)$ & \\
\hline $\begin{array}{l}\text { Index ulcer on plantar } \\
\text { aspect of foot }\end{array}$ & $37(58)$ & $8(80)$ & $7(58)$ & $22(52)$ & 0.276 \\
\hline Index ulcer size in $\mathrm{cm}^{2}$ & $3(2-5)$ & $4(3-4)$ & $5(2-7)$ & $3(2-4)$ & 0.367 \\
\hline $\begin{array}{l}\text { SINBAD classification } \\
\text { score [34] }\end{array}$ & $5(4-5)$ & $5(4-5)$ & $5(4-5)$ & $5(5-5)$ & 0.153 \\
\hline
\end{tabular}

Previous treatment of DFO

- $\quad$ Surgical resection

$\begin{array}{llll}\begin{array}{l}\text { and antibiotic } \\ \text { therapy }\end{array} & 16(25) & 2(20) & 3(25)\end{array}$

- $\quad$ Minor amputation and antibiotic

- $\quad$ Antibiotic therapy only

- Endovascular procedure

- $\quad$ Antibiotic therapy only

Surgical procedure with gentamicin-loaded CaS-HA biocomposite involved a minor amputation

Fixation methods used in the surgical procedure with gentamicin-loaded CaS-HA biocomposite

- None

- Internal fixation

- External fixation
55 (86)

7 (11)

2 (3)
10 (100)

0

0
9 (75)

36 (86)

2 (17)

$5(12)$

$1(8)$ 
Table 1. Cont

\begin{tabular}{|c|c|c|c|c|c|}
\hline Characteristics & All Patients & $\begin{array}{c}\text { Patients with } \\
\text { Persistent Wounds }\end{array}$ & $\begin{array}{l}\text { Patients with } \\
\text { Ulcer Recurrence }\end{array}$ & $\begin{array}{c}\text { Patients with } \\
\text { Treatment Success }\end{array}$ & $p$ Value \\
\hline \multicolumn{6}{|c|}{ Microbiological analysis of osteomyelitis } \\
\hline $\begin{array}{l}\text {-Bone samples not } \\
\text { obtained }\end{array}$ & $15(23)$ & $3(30)$ & $2(17)$ & $10(24)$ & 0.755 \\
\hline $\begin{array}{l}\text {-Monomicrobial } \\
\text { infection }\end{array}$ & $24(38)$ & $2(20)$ & $3(25)$ & $19(45)$ & 0.779 \\
\hline - $\quad$ AGP pathogen & $16(25)$ & $2(20)$ & $2(17)$ & $12(28)$ & \\
\hline - $\quad$ AGN pathogen & $8(12)$ & 0 & $1(8)$ & $7(17)$ & \\
\hline $\begin{array}{ll}\text { - } & \text {-Polymicrobial } \\
\text { infection }\end{array}$ & $25(39)$ & $5(50)$ & $7(58)$ & $13(31)$ & 0.179 \\
\hline - $\quad$ AGP pathogens & $11(17)$ & $1(10)$ & $2(17)$ & $8(19)$ & \\
\hline $\begin{array}{l}\text { - AGP pathogens and } \\
\text { AGN pathogens }\end{array}$ & $13(20)$ & $3(30)$ & $5(42)$ & $5(12)$ & \\
\hline $\begin{array}{l}\text { - AGP pathogens and } \\
\text { OA pathogens }\end{array}$ & $1(2)$ & $1(10)$ & 0 & 0 & \\
\hline $\begin{array}{ll}\text { - } & \text {-Gentamicin- } \\
\text { resistant } \\
\text { osteomyelitis }\end{array}$ & $3(5)$ & $2(20)$ & $1(8)$ & 0 & $0.020 \ddagger$ \\
\hline
\end{tabular}

Data are presented as number (\%), mean $\pm \mathrm{SD}$, or median (IQR). A $p$-value $<0.05$ indicates significant differences between patient groups regarding the distribution of cases or reported values. For these variables, results of post hoc analyses with adjusted $p$-values by Bonferroni correction are presented in the footnote. SINBAD: Site, Ischemia, Neuropathy, Bacterial infection, Area, Depth classification. DFO: Diabetic foot ulcers complicated by osteomyelitis. CaS-HA: Calcium sulphate-hydroxyapatite. AGP: Aerobic, Gram-Positive. AGN: Aerobic Gram-negative. OA: Obligate anaerobic. * Postoperative follow-up, which was completed until amputation, repeated surgical resection of $\mathrm{DFO}$, death, or the last-mentioned consultation in the electronic health record system, was significantly $(p=0.002)$ shorter in patients with persistent wounds. ${ }^{* *}$ Distribution of Charcot osteoarthropathy was not significantly different between patient groups. ${ }^{* * *}$ Distribution of limb ischemia was not significantly different between patient groups. ${ }^{\dagger}$ Index ulcer duration was significantly longer in patients with ulcer recurrence $(p=0.014)$. ${ }^{+t}$ Of patients with persistent wounds, a significantly larger proportion underwent surgical procedures with gentamicin-loaded CaS-HA biocomposite that involved a minor amputation $(p=0.004)$. $¥$ Of patients with persistent wounds, a significantly larger proportion had gentamicin-resistant $\mathrm{DFO}(p=0.007)$.

\subsection{Primary Outcomes}

Median postoperative follow-up was 43 (IQR, 20-61) weeks (Table 1). We observed uncomplicated wound healing in 54 patients $(84 \%)$ and a median time to wound healing of 9 (IQR, 5-16) weeks (Figure 2). Of 10 patients (16\%) with persistent wounds, four underwent minor amputations during follow-up, four underwent major amputations, one underwent repeated surgical resection of DFO without antibiotic-loaded CaS-HA biocomposite, and one still had an ongoing wound at a final follow-up of 14 weeks (Figure 2). Recurrent foot ulcers were observed in 12 of 54 patients (22\%) after initial postoperative wound healing, and the median time to ulcer recurrence was 24 (IQR, 16-46) weeks (Figure 2). Thus, the rate of treatment success was $66 \%$ (42 patients) overall (Figure 2).

Of 12 patients (19\%) with ulcer recurrence, three underwent major amputations, three underwent repeated surgical resections of DFO without antibiotic-loaded CaS-HA biocomposite, three underwent successful conservative treatments by antibiotic therapy and offloading and three had ongoing ulcers at final follow-up (Figure 2). In patients with ulcer 
recurrence, the preoperative index ulcer lasted significantly longer compared with patients without ulcer recurrence (median, 37 (IQR, 21-79) weeks vs. median 18 (IQR, 10-43) weeks, respectively; $p=0.014$ ) (Table 1$)$. Furthermore, a significantly larger proportion of patients with persistent wounds $(n=4(40 \%))$ underwent surgical procedures with gentamicinloaded CaS-HA biocomposite that involved minor amputations compared with patients with ulcer recurrence $(n=3(25 \%))$ or treatment success $(n=1(2 \%) ; p=0.004)$ (Table 1$)$.

\subsection{Secondary Outcomes}

After a median follow-up of 8 (IQR, 5-23) weeks, minor amputations were performed because of treatment failures in four patients $(6 \%)$, of whom two initially underwent surgical procedures with gentamicin-loaded CaS-HA biocomposite that involved minor amputations (Figure 2). Major amputations were performed after a median follow-up of 17 (IQR, 7-41) weeks in seven patients (11\%), of whom five initially underwent surgical procedures with gentamicin-loaded CaS-HA biocomposite that involved minor amputations (Figure 2). At the final follow-up, 50 patients $(78 \%)$ could mobilize weight-bearing, including 11 patients (17\%) who had treatment failures (Figure 2). Of these 50 patients, $48(96 \%)$ used custom-made or prefabricated therapeutic footwear, and two $(4 \%)$ used prefabricated footwear at final follow-up. Three of 14 patients (22\%) who were unable to mobilize weight-bearing had pre-existent incomplete paraplegia (Figure 2).

\subsection{Treatment Failures}

Patients with persistent wounds (defined as treatment failure at day one for timebased analyses) and patients with ulcer recurrence after initial postoperative wound healing are demonstrated in the Kaplan-Meier curve in Figure 3. In univariable Cox regression analysis, factors that were independently associated with treatment failure were gentamicinresistant $\mathrm{DFO}$, index ulcer location and surgical procedures with gentamicin-loaded CaSHA biocomposite that involved a minor amputation (Table 2).

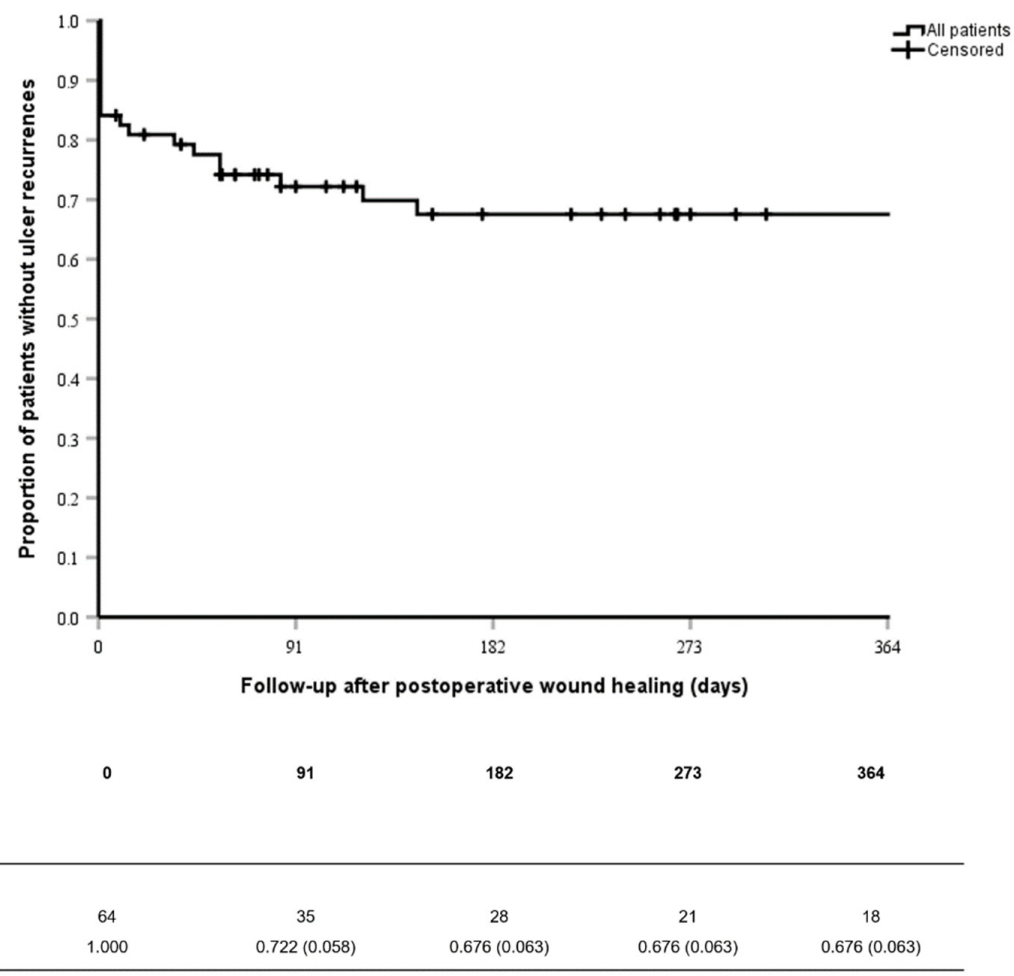

Figure 3. Kaplan-Meier curve demonstrating treatment failures (persistent wounds or ulcer recurrence after initial postoperative wound healing) of surgical treatments with gentamicin-loaded calcium sulphate-hydroxyapatite biocomposite of diabetic foot ulcers complicated by osteomyelitis. Patients with persistent wounds are demonstrated as having an event at day 1. SE: Standard error. 
Table 2. Univariable $(p<0.05)$ Cox regression analysis for treatment failures after surgical treatments of diabetic foot osteomyelitis with gentamicin-loaded calcium sulphate-hydroxyapatite biocomposite.

\begin{tabular}{lcc}
\hline \multirow{2}{*}{ Characteristic } & \multicolumn{2}{c}{ Univariable Analysis } \\
\cline { 2 - 3 } & Hazard Ratio (95\%-CI) & $p$ Value \\
\hline Gentamicin-resistant osteomyelitis & $3.847(1065-13.899)$ & 0.040 \\
\hline Index ulcer location & Reference & 0.029 \\
Forefoot & & 0.028 \\
Midfoot & $3.022(1127-8104)$ & 0.024 \\
Hindfoot & $3.624(1187-11.060)$ & \\
\hline $\begin{array}{l}\text { Surgical procedure with gentamicin-loaded } \\
\text { CaS-HA biocomposite involved a } \\
\text { minor amputation }\end{array}$ & $3.965(1608-9777)$ & 0.003 \\
\hline
\end{tabular}

CI: Confidence interval. CaS-HA: Calcium sulphate-hydroxyapatite.

\subsection{Microbiological Analysis}

Bone samples were obtained in 49 patients (76\%). Microbiological analysis yielded a median of two (IQR, 1-3) pathogens per patient. Osteomyelitis was monomicrobial in 24 patients (38\%) and polymicrobial in 25 patients (39\%), with Staphylococcus aureus as the most frequently isolated pathogen in both groups (Table 1, Figure 4).

A Monomicrobial diabetic foot osteomyelitis
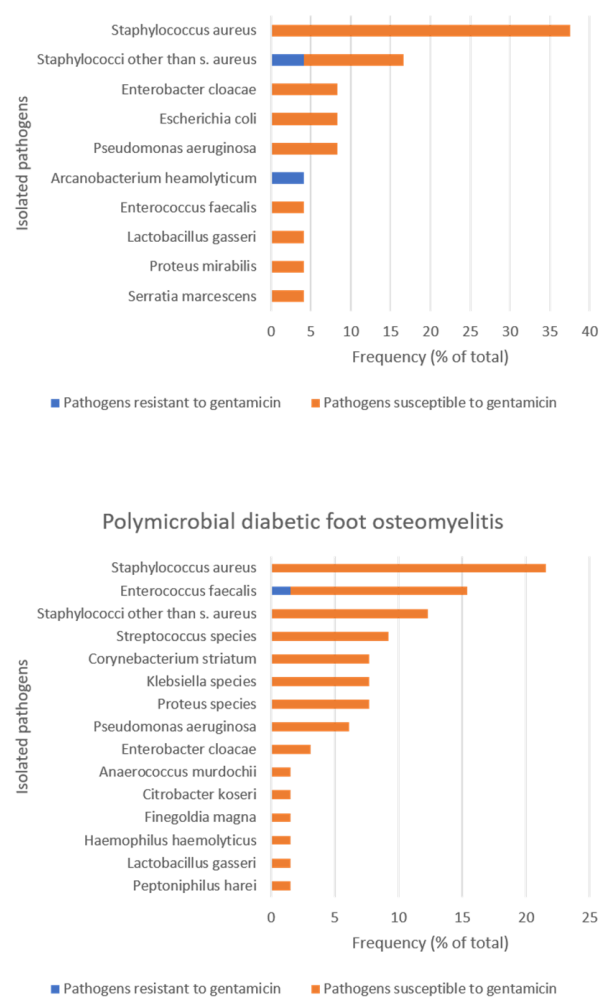

Figure 4. Pathogens isolated in bone samples of 49 patients with diabetic foot ulcers complicated by osteomyelitis. (A) Distribution of pathogens isolated in 16 patients with monomicrobial osteomyelitis. (B) Distribution of 87 pathogens isolated in 33 patients with polymicrobial osteomyelitis. Gentamicinresistance of pathogens was based on the minimal inhibitory concentration breakpoints of the European Committee on Antimicrobial Sensitivity Testing (EUCAST). 


\subsection{Postoperative Treatment}

Postoperative antibiotic therapy was administered in 26 patients (41\%) for a median of 3 (IQR, 2-6) weeks. Postoperative antibiotic therapy was administered to four patients $(40 \%)$ without postoperative wound healing, which was not significantly $(p=0.930)$ different from patients with ulcer recurrence $(n=4(33 \%))$ or without ulcer recurrence $(n=18$ $(43 \%))$. Postoperative offloading was performed in all patients for median 6 (IQR, 5-8) weeks by non-weight-bearing mobilization $(n=33(52 \%))$, nonremovable knee-high devices $(n=14(22 \%))$, removable knee-high devices $(n=2(3 \%))$ and removable ankle-high devices $(n=15(3 \%))$.

\subsection{Adverse Events}

Readmissions, reoperations and adverse events are listed in Figure 2. Charcot osteoarthropathy exacerbations were observed in two of 18 patients $(11 \%)$ with Charcot osteoarthropathy during follow-up (Figure 2). After 23 weeks of follow-up, one patient with postoperative wound healing without ulcer recurrence died of cardiac disease. No other patients were lost to follow-up.

\section{Discussion}

In this multicenter, retrospective cohort study, we investigated the treatment of DFO with gentamicin-loaded CaS-HA biocomposite in patients where conventional treatment had failed. Treatment success was observed in $66 \%$ of patients during median 43 weeks of follow-up. Treatment failure due to a persistent wound or ulcer recurrence after initial postoperative wound healing was observed in $15 \%$ and $19 \%$ of patients, respectively. After treatment failure, minor and major amputations were required in $6 \%$ and $11 \%$ of patients, respectively. Furthermore, $78 \%$ of patients could mobilize weight-bearing at final followup, including $17 \%$ patients with treatment failures. These findings confirm results from previous studies and show that surgical treatment with gentamicin-loaded CaS-HA biocomposite is feasible for patients with DFO after failed conventional treatments [23,24,28,29].

Our findings correspond with previous publications of this treatment regimen regarding wound healing rates (details are listed in Table 3) $[23,24,28,29]$. However, there are important differences between our study and previous publications regarding locations of DFO, surgical procedures and postoperative treatments. First, contrary to previous studies in which patients with midfoot or hindfoot DFO were predominantly included, we mainly included patients with forefoot DFO [24,28,29]. 
Table 3. Previous studies of treatments of diabetic foot osteomyelitis with gentamicin-loaded calcium sulphate-hydroxyapatite biocomposite.

\begin{tabular}{|c|c|c|c|c|c|c|}
\hline $\begin{array}{l}\text { Author } \\
\text { (Year) }\end{array}$ & Study Design & Patients & Intervention & Follow-Up & Results & QUADAS-2 Score [37] \\
\hline \multirow{4}{*}{$\begin{array}{l}\text { This } \\
\text { study }\end{array}$} & \multirow{4}{*}{$\begin{array}{l}\text { Multicenter } \\
\text { RCS }\end{array}$} & \multirow{4}{*}{$\begin{array}{l}\text { Inclusion of } 64 \text { patients with } \\
\text { DFO after unsuccessful } \\
\text { conventional treatment } \\
\text { (antibiotic therapy alone, or } \\
\text { surgical debridement or minor } \\
\text { amputation with adjunctive } \\
\text { antibiotic therapy). }\end{array}$} & $\begin{array}{l}\text { - Surgical debridement, dead } \\
\text { space filling with } \\
\text { gentamicin-loaded CaS-HA } \\
\text { biocomposite, closure of } \\
\text { skin and soft tissues. } \\
\text { Procedures involved minor } \\
\text { amputations in } \\
8 \text { patients }(13 \%) .\end{array}$ & \multirow{4}{*}{$\begin{array}{l}\text { Median } 43 \\
\text { (IQR, 20-61) weeks. }\end{array}$} & $\begin{array}{l}\text { - Wound healing in } \\
54 \text { patients }(84 \%) \text { and } \\
\text { treatment success in } \\
42(66 \%) .\end{array}$ & Risk of bias: \\
\hline & & & $\begin{array}{l}\text { Postoperative offloading } \\
\text { by non-weight bearing } \\
\text { mobilization in } 33 \text { patients } \\
(52 \%), \text { nonremovable } \\
\text { knee-high devices in } \\
14(22 \%), \text { removable } \\
\text { knee-high devices in } \\
2(3 \%), \text { and removable } \\
\text { ankle-high devices in } \\
15(23 \%) \text { for median } \\
6(\mathrm{IQR}, 5-8) \text { weeks. }\end{array}$ & & $\begin{array}{l}\text { Treatment failures (no } \\
\text { wound healing) in } \\
10 \text { patients }(12 \%) \text {. }\end{array}$ & - $\quad$ Patient selection: Low risk \\
\hline & & & \multirow{2}{*}{$\begin{array}{l}\text { Postoperative antibiotic } \\
\text { therapy in } 26 \text { patients } \\
\text { (41\%) for a median } 3 \text { (IQR, } \\
\text { 2-6) weeks. }\end{array}$} & & $\begin{array}{l}\text { Treatment failures } \\
\text { (ulcer recurrence) in } \\
12 \text { patients }(19 \%) .\end{array}$ & - Index test: N/A \\
\hline & & & & & $\begin{array}{l}\text { Minor amputations in } 4 \\
\text { patients }(6 \%) \text { and } \\
\text { major amputations in } \\
7(11 \%) \text { because of } \\
\text { treatment failures. }\end{array}$ & - Reference standard: N/A \\
\hline
\end{tabular}


Table 3. Cont.

\begin{tabular}{|c|c|c|c|c|c|c|}
\hline $\begin{array}{l}\text { Author } \\
\text { (Year) }\end{array}$ & Study Design & Patients & Intervention & Follow-Up & Results & QUADAS-2 Score [37] \\
\hline & & & & & \multirow{4}{*}{$\begin{array}{l}\text { Weight-bearing } \\
\text { mobilization at final } \\
\text { follow-up in } \\
50 \text { patients }(89 \%) \text {. }\end{array}$} & - $\quad$ Flow and timing: Low risk \\
\hline & & & & & & Applicability concerns: \\
\hline & & & & & & - $\quad$ Patient selection: Low risk \\
\hline & & & & & & $\begin{array}{l}\text { - Reference standard: } \\
\text { Low risk }\end{array}$ \\
\hline \multirow{3}{*}{$\begin{array}{l}\text { Whisstock, } \\
\text { et al. [29] } \\
(2020)\end{array}$} & \multirow{3}{*}{$\begin{array}{l}\text { Single- } \\
\text { center } \\
\text { RCS }\end{array}$} & \multirow{3}{*}{$\begin{array}{l}\text { Inclusion of } 35 \text { patients (aged } \\
18-80 \text { years) with DFO, with } \\
\text { or without Charcot } \\
\text { neuroarthropathy and an } \\
\text { otherwise normal function of } \\
\text { the lower extremity. }\end{array}$} & $\begin{array}{l}\text { Surgical debridement, } \\
\text { dead space filling with } \\
\text { gentamicin-loaded } \\
\text { CaS-HA biocomposite. } \\
\text { Procedures involved } \\
\text { partial calcanectomies in } \\
3 \text { patients, talectomy in } 1, \\
\text { and external fixation in } \\
6(17 \%) .\end{array}$ & \multirow{3}{*}{$\begin{array}{l}12 \text { months. Three } \\
\text { patients lost to } \\
\text { follow-up. }\end{array}$} & $\begin{array}{l}\text { - } \quad \text { Bone infection cured in } \\
26 \text { patients }(81 \%) .\end{array}$ & Risk of bias: \\
\hline & & & $\begin{array}{l}\text { - Closure with dermal } \\
\left.\text { substitute (Hyalomatrix }{ }^{\mathrm{TM}}\right) \\
\text { in } 10 \text { patients }(29 \%) \text {. }\end{array}$ & & $\begin{array}{l}\text { - Due to nonhealing, } \\
1 \text { minor and } 3 \text { major } \\
\text { amputations were } \\
\text { performed. }\end{array}$ & - $\quad$ Patient selection: Low risk \\
\hline & & & $\begin{array}{l}\text { Postoperative antibiotic } \\
\text { therapy for 4-6 weeks }\end{array}$ & & $\begin{array}{l}\text { Weight-bearing } \\
\text { mobilization was } \\
\text { possible in } 25 \text { patients } \\
(96 \%) \text { with cured bone } \\
\text { infections }\end{array}$ & - Index test: N/A \\
\hline
\end{tabular}


Table 3. Cont.

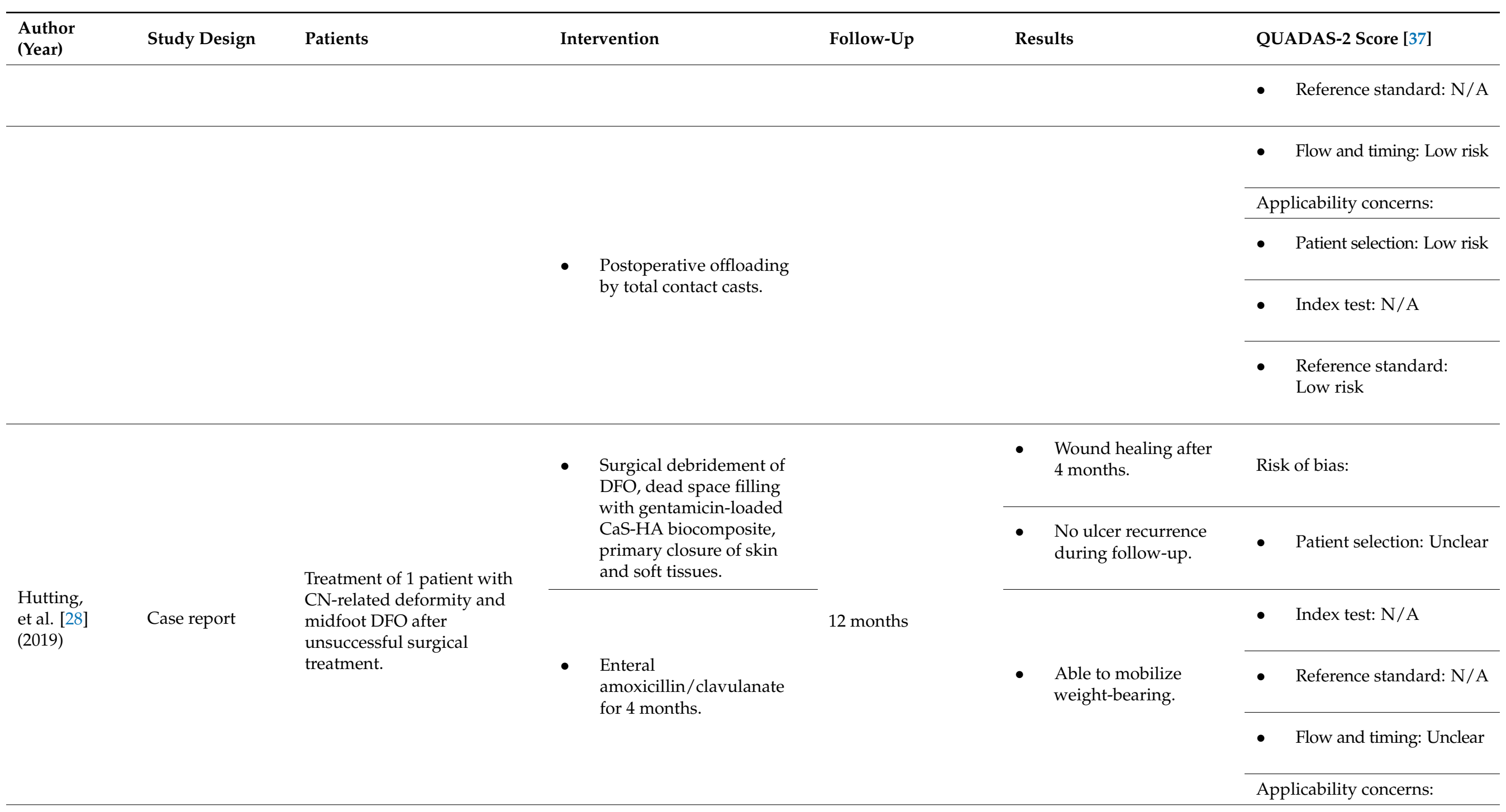


Table 3. Cont.

\begin{tabular}{|c|c|c|c|c|c|c|}
\hline $\begin{array}{l}\text { Author } \\
\text { (Year) }\end{array}$ & Study Design & Patients & Intervention & Follow-Up & Results & QUADAS-2 Score [37] \\
\hline & & & & & & - $\quad$ Patient selection: Low risk \\
\hline & & & & & & - Index test: N/A \\
\hline & & & & & & $\begin{array}{l}\text { - Reference standard: } \\
\text { Low risk }\end{array}$ \\
\hline \multirow{4}{*}{$\begin{array}{l}\text { Niazi, } \\
\text { et al. [23] } \\
(2019)\end{array}$} & \multirow{4}{*}{$\begin{array}{l}\text { Multicenter } \\
\text { RCS }\end{array}$} & \multirow{4}{*}{$\begin{array}{l}\text { Inclusion of } 70 \text { patients with } \\
\text { DFO of the forefoot }(62 \%) \text {, } \\
\text { midfoot }(33 \%) \text {, or hindfoot } \\
(5 \%) \text {. CN-related deformity in } \\
9 \text { patients }(13 \%)\end{array}$} & $\begin{array}{l}\text { - Surgical debridement of } \\
\text { DFO, dead space filling } \\
\text { with gentamicin-loaded } \\
\text { CaS-HA biocomposite } \\
\text { (using the "Silo technique" } \\
\text { in case of calcaneal DFO) } \\
\text { [24], primary closure of } \\
\text { skin and soft tissues or } \\
\text { VAC. Procedures involved } \\
\text { minor amputations in } \\
2 \text { patients }(3 \%) .\end{array}$ & \multirow{4}{*}{$\begin{array}{l}\text { Mean } 10 \\
\text { (range, 4-28) months }\end{array}$} & $\begin{array}{l}\text { Wound healing in } 57 \\
\text { patients }(81 \%) \text { after a } \\
\text { mean of } 12 \text { (range, } \\
\text { 4-16) weeks. }\end{array}$ & Risk of bias: \\
\hline & & & \multirow{3}{*}{$\begin{array}{l}\text { - Antibiotic therapy for } \\
\text { mean } 4 \text { (range, 2-6) weeks. }\end{array}$} & & $\begin{array}{l}\text { Eradication of infection } \\
\text { in } 63 \text { patients }(90 \%) \text {. }\end{array}$ & - $\quad$ Patient selection: High risk \\
\hline & & & & & $\begin{array}{l}\text { Treatment failures in } 7 \\
\text { patients }(10 \%) .\end{array}$ & - Index test: N/A \\
\hline & & & & & $\begin{array}{l}\text { - Major amputations in } 5 \\
\text { patients }(7 \%) \text { due to } \\
\text { treatment failures. }\end{array}$ & - $\quad$ Reference standard: N/A \\
\hline
\end{tabular}


Table 3. Cont.

\begin{tabular}{|c|c|c|c|c|c|c|}
\hline $\begin{array}{l}\text { Author } \\
\text { (Year) }\end{array}$ & Study Design & Patients & Intervention & Follow-Up & Results & QUADAS-2 Score [37] \\
\hline & & & & & \multirow{5}{*}{$\begin{array}{l}\text { - No recurrence } \\
\text { of infection. }\end{array}$} & $\begin{array}{l}\text { - Flow and timing: } \\
\text { High risk }\end{array}$ \\
\hline & & & & & & Applicability concerns: \\
\hline & & & & & & $\begin{array}{l}\text { - Patient selection: } \\
\text { Low risk }\end{array}$ \\
\hline & & & & & & - Index test: N/A \\
\hline & & & & & & $\begin{array}{l}\text { - Reference standard: } \\
\text { Low risk }\end{array}$ \\
\hline \multirow{4}{*}{$\begin{array}{l}\text { Drampalos, } \\
\text { et al. [24] } \\
(2018)\end{array}$} & \multirow{4}{*}{$\begin{array}{l}\text { Single-center } \\
\text { RCS }\end{array}$} & \multirow{4}{*}{$\begin{array}{l}\text { Inclusion of } 12 \text { patients with } \\
\text { calcaneal DFO without } \\
\text { involvement of the posterior } \\
\text { subtalar joint. }\end{array}$} & $\begin{array}{l}\text { - Surgical resection, filling of } \\
\text { drilled tunnels in the } \\
\text { calcaneus with } \\
\text { gentamicin-loaded } \\
\text { CaS-HA biocomposite } \\
\text { ("Silo technique"), primary } \\
\text { closure or VAC. }\end{array}$ & \multirow{4}{*}{$\begin{array}{l}\text { Mean } 16 \\
\text { (range, 12-18) weeks }\end{array}$} & $\begin{array}{l}\text { Wound healing in } 12 \\
\text { patients (100\%) after } \\
\text { mean 16 (range, 12-18) } \\
\text { weeks. }\end{array}$ & Risk of bias: \\
\hline & & & \multirow{3}{*}{$\begin{array}{l}\text { - Antibiotic therapy for } \\
6-12 \text { weeks. }\end{array}$} & & \multirow{3}{*}{$\begin{array}{l}\text { - Postoperative } \\
\text { ambulation in } \\
6 \text { patients. }\end{array}$} & $\begin{array}{l}\text { - Patient selection: } \\
\text { High risk }\end{array}$ \\
\hline & & & & & & - Index test: N/A \\
\hline & & & & & & - $\quad$ Reference standard: N/A \\
\hline
\end{tabular}


Table 3. Cont.

\begin{tabular}{|c|c|c|c|c|c|c|}
\hline $\begin{array}{l}\text { Author } \\
\text { (Year) }\end{array}$ & Study Design & Patients & Intervention & Follow-Up & Results & QUADAS-2 Score [37] \\
\hline & & & & & & $\begin{array}{l}\text { - Flow and timing: } \\
\text { High risk }\end{array}$ \\
\hline & & & & & & Applicability concerns: \\
\hline & & & & & & $\begin{array}{l}\text { - Patient selection: } \\
\text { Low risk }\end{array}$ \\
\hline & & & & & & - Index test: N/A \\
\hline & & & & & & $\begin{array}{l}\text { - Reference standard: } \\
\text { Low risk }\end{array}$ \\
\hline
\end{tabular}

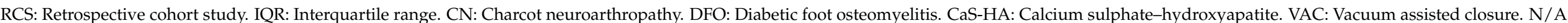
Not applicable. 
Second, the surgical procedures with gentamicin-loaded CaS-HA biocomposite involved minor amputations in $13 \%$ of patients in our study, whereas these were only reported in one previous study in two of 70 patients [23]. This is probably the result of the high proportion of patients with forefoot DFO in our study, in whom complete surgical resection sometimes can only be performed by minor amputation.

Third, only $41 \%$ of patients in our study received postoperative antibiotic therapy, whereas all patients were administered postoperative antibiotic therapy for several weeks in previous studies $[23,24,28,29]$. This difference is probably caused by the lack of uniform treatment protocols. The observed success rate, obtained in a study population of which more than half was not treated by postoperative antibiotic therapy, could suggest that systemic antibiotic therapy is not indicated in all patients after treatment with gentamicinloaded CaS-HA biocomposite. However, further investigation of the role of systemic antibiotic therapy in this treatment regimen is required before recommendations can be made.

Finally, vacuum-assisted closure of surgical wounds was not performed in our study, whereas this was performed in up to $50 \%$ of patients in previous studies $[23,24]$. These differences limit comparisons of our study with previous publications, and indicate that uniform protocols are needed regarding patient selection, surgical procedures and postoperative treatment for this treatment regimen.

The ultimate treatment goal in people with DFO is to become ulcer-free. Therefore, our definition of treatment failure includes ulcer recurrence. Because only postoperative wound healing was considered in previous studies of this treatment regimen, reported success rates might be overestimated [23,24,29]. We postulate that ulcer recurrence should be included in the definitions of treatment failure in future studies. Furthermore, we recommend reporting details regarding offloading and other ulcer prevention strategies in future treatment protocols, because inadequate offloading is one of the possible causes for ulcer recurrence [35].

In this study, we explored potential risk factors for treatment failures. In a univariable analysis, gentamicin-resistant $\mathrm{DFO}$, hindfoot $\mathrm{DFO}$ and surgical procedures with gentamicin-loaded CaS-HA biocomposite that involved minor amputations were associated with treatment failures. These results should be interpreted with caution given the high confidence intervals and the small sample size with a limited number of events. However, since these potential associations might be clinically relevant, they should be investigated further. These investigations should include postoperative offloading, since the potential association between hindfoot DFO and treatment failures could be the result of offloading difficulties [38-40].

Amputations are frequently performed in patients with DFO after unsuccessful conventional treatments $[10,11]$. Minor and major amputations were performed in $6 \%$ and $11 \%$ of patients, respectively, after failed treatments with gentamicin-loaded CaS-HA biocomposite in our study. These rates are higher than the rates of minor $(0-3 \%)$ and major (7-9\%) amputations reported in previous studies of this treatment regimen [23,29]. This is probably caused by the inclusion of patients after failed conventional treatments, who had no options left after failure of treatment with gentamicin-loaded CaS-HA biocomposite. However, considering the selection of patients after failed conventional treatments, the observed rates of minor and major amputations were lower than expected. These findings warrant further research into this new treatment regimen, in which amputations performed after treatment failures should also be investigated.

Our study has several limitations. First, the retrospective design imposes a risk of bias. Second, the absence of current protocols for the surgical procedures and postoperative treatments resulted in a heterogeneous study population. Even though we included almost all patients treated with gentamicin-loaded CaS-HA biocomposite, and therefore obtained a representative study population for current clinical practice in the Netherlands, the resulting heterogeneity introduces various confounding factors which limit the conclusions that can be drawn. Third, the included study population was relatively small. Even 
though it is larger than in most previous studies, the small study population increases statistical errors. Therefore, the analyses performed should be considered exploratory and be interpreted cautiously. Fourth, our study is limited by the lack of a control group. In future prospective studies, a uniformed treatment regimen should be compared to a control cohort of patients treated by conventional treatments. Fifth, adequate investigation of ulcer recurrence was limited by the median follow-up of 43 weeks, which should ideally be 12 or 18 months after initial wound healing for this purpose [1]. Sixth, specific information regarding diabetes mellitus (i.e., glycemic control) and other risk factors for vascular disease (e.g., dyslipidemia or smoking status) was lacking, as well as details regarding the preoperative discontinuation of antibiotic therapy and the number and exact sites where bone samples were obtained. Seventh, we did not include a minimal postoperative duration in the definition of persistent wounds, which should be considered in further prospective studies. Eight, pre-operative functional status was not investigated in the assessment of functional results. Finally, assessment of persistent or recurrent osteomyelitis in patients with treatment failures was not possible, since additional investigations (e.g., imaging, bone samples) were not performed consistently. Future prospective studies will overcome these limitations.

Uniform treatment protocols are required for the treatment of DFO with gentamicinloaded CaS-HA biocomposite. For a uniform treatment protocol, suggestions for patient selection should include patients with DFO after unsuccessful treatment by antibiotic therapy for at least 6 weeks [14]. Patients with severe limb ischemia should be excluded [33]. Regarding the surgical procedures, we advocate thorough surgical resection of DFO and obtaining multiple bone samples. Regarding postoperative treatments, we suggest offloading in accordance with the IWGDF guidelines until postoperative wound healing is observed, at least several days of postoperative antibiotic therapy based on the results of microbiological analysis of bone samples, and structural follow-up in a multidisciplinary setting [14,41]. Prospective investigation of treatment protocols, based on the insights reported in our study and previous studies, is required $[23,24,28,29]$. This prospective investigation should consider postoperative wound healing, ulcer recurrence, amputations and functional results in comparison to the pre-operative functional status.

In conclusion, surgical treatment with gentamicin-loaded CaS-HA biocomposite was feasible in this study of patients with DFO and successful in $66 \%$ of patients. A prospective trial of this treatment regimen, based on uniform treatment protocols, is required.

Author Contributions: Conceptualization, K.H.H., W.A.t.C., G.M.J.M.W., J.-P.P.M.d.V. and J.G.v.B.; Methodology, K.H.H., W.B.a.d.S., J.J.v.N. and J.-P.P.M.d.V.; Software, K.H.H., W.B.a.d.S., and J.J.v.N.; Validation, W.A.t.C., L.S., G.M.J.M.W. and D.M.S.; Formal analysis, K.H.H. and W.B.a.d.S.; Investigation, K.H.H., W.B.a.d.S., J.J.v.N., W.A.t.C., L.S., G.M.J.M.W. and D.M.S.; Resources, W.A.t.C., L.S., G.M.J.M.W., D.M.S., J.-P.P.M.d.V. and J.G.v.B.; Data curation, K.H.H., W.A.t.C., L.S., G.M.J.M.W. and D.M.S.; Writing—original draft preparation, K.H.H., W.B.a.d.S. and J.J.v.N.; Writing-review and editing, J.J.v.N., J.-P.P.M.d.V. and J.G.v.B.; Visualization, K.H.H.; Supervision, J.-P.P.M.d.V. and J.G.v.B.; Project administration, K.H.H.; Funding acquisition, not applicable. All authors have read and agreed to the published version of the manuscript.

Funding: This research received no external funding.

Institutional Review Board Statement: The study was conducted according to the guidelines of the Declaration of Helsinki and the Dutch Personal Data Protection Act. The study was approved by the Medical Ethics Committee Twente of Hospital Group Twente and Medical Spectrum Twente (K18-33, date of approval: 26 July 2018).

Informed Consent Statement: Informed consent was obtained from all subjects involved in the study.

Data Availability Statement: The data presented in this study are available on request from the corresponding author. The data are not publicly available due to confidentiality agreements. Supporting data can only be made available to bona fide researchers subject to a non-disclosure agreement. Details of the data and how to request access are available from Kor H. Hutting [ko.hutting@zgt.nl; 
003188-7084232] at Hospital Group Twente, Department of Surgery, Zilvermeeuw 1, 7609 PP Almelo, The Netherlands.

Acknowledgments: For their advice and contribution regarding microbiological aspects of our study, we thank Nashwan Al Naiemi, and Dorine Hess of Laboratory for Microbiology TwenteAchterhoek. We thank the following local investigators for their contribution to this study: Bart A.N. Verhoeven, Jeroen Bosch Hospital, Department of Vascular Surgery. Henri Dunantstraat 1, 5223 GZ, 's-Hertogenbosch, Noord-Brabant, the Netherlands.; Bart-Jeroen Petri, University Medical Centre Utrecht, Department of Vascular Surgery. Heidelberglaan 100, 3584 CX, Utrecht, Utrecht, the Netherlands; Casper P.C. Smit, Reinier de Graaf Hospital, Department of Vascular Surgery. Reinier de Graafweg 5, 2625 AD, Delft, Zuid-Holland, the Netherlands; Eline S. van Hattum, University Medical Centre Utrecht, Department of Vascular Surgery. Heidelberglaan 100, 3584 CX, Utrecht, Utrecht, the Netherlands; George P. Akkersdijk, Maasstad Hospital, Department of Vascular Surgery. Maasstadweg 21, 3079 DZ, Rotterdam, Zuid-Holland, the Netherlands; Marie Josee E. van Rijn, Erasmus University Medical Centre, Department of Vascular Surgery. Doctor Molewaterplein 40, 3015 GD, Rotterdam, Zuid-Holland, the Netherlands; Olaf J. Bakker, St. Antonius Hospital, Department of Vascular Surgery. Koekoekslaan 1, 3435 CM, Nieuwegein, Utrecht, the Netherlands; Patricia van Mierlo-van den Broek, M.A.N.P., Maasstad Hospital, Department of Vascular Surgery. Maasstadweg 21, 3079 DZ, Rotterdam, Zuid-Holland, the Netherlands; Steven E. Buijk, IJsselland Hospital, Department of Vascular Surgery. Prins Constantijnweg 2, 2906 ZC, Capelle aan den IJssel, Zuid-Holland, the Netherlands; Ties M.G. van Andringa de Kempenaer, Medical Centre Leeuwarden, Department of Vascular Surgery. Henri Dunantweg 2, 8934 AD, Leeuwarden, Friesland, the Netherlands; Wout B. Barendregt, Canisius-Wilhelmina Hospital, Department of Vascular Surgery. Weg door Jonkerbos 100, 6532 SZ, Nijmegen, Gelderland, the Netherlands.

Conflicts of Interest: All authors declare that they have no conflicting financial or non-financial interests regarding the subject matter or the materials discussed in this article. While conducting the data collection in this study, we contacted the only firm (iMove medical B.V., Nieuwegein, the Netherlands) that distributed gentamicin-loaded calcium sulphate-hydroxyapatite biocomposite in the Netherlands during the study period, to obtain a complete list of Dutch hospitals in which treatments with this material were performed. We used this information to make contacts with the treating physicians in these hospitals, without involvement of iMove medical B.V. No agreements were made with IMove Medical B.V., and this firm had no further involvement or control in this study whatsoever.

\section{Appendix A}

Table A1. Surgical procedures with gentamicin-loaded calcium sulphate-hydroxyapatite biocomposite performed to treat diabetic foot ulcers complicated by osteomyelitis in this study.

\begin{tabular}{lc}
\multicolumn{1}{c}{ Surgical Procedures } & No. (\%) \\
\hline $\begin{array}{l}\text { Osteotomy of phalanx/phalanges, debridement and dead space filling } \\
\text { with gentamicin-loaded CaS-HA biocomposite. }\end{array}$ & $3(5)$ \\
\hline $\begin{array}{l}\text { Arthrotomy of interphalangeal joint(s), resection with base and head of } \\
\text { adjacent phalanges, dead space filling with gentamicin-loaded CaS-HA } \\
\text { biocomposite. }\end{array}$ & $3(5)$ \\
\hline $\begin{array}{l}\text { Arthrotomy of interphalangeal joint(s), resection with base and head of } \\
\text { adjacent phalanges, dead space filling with gentamicin-loaded CaS-HA } \\
\text { biocomposite, arthrodesis with Kirschner wire. }\end{array}$ & $3(5)$ \\
\hline $\begin{array}{l}\text { Arthrotomy of metatarsophalangeal joint(s), resection with metatarsal } \\
\text { head(s) and base of proximal phalanx/phalanges, dead space filling with } \\
\text { gentamicin-loaded CaS-HA biocomposite. }\end{array}$ & $14(22)$ \\
\hline $\begin{array}{l}\text { Arthrotomy of metatarsophalangeal joint(s), resection with metatarsal } \\
\text { head(s) and base of proximal phalanx/phalanges, dead space filling with } \\
\text { gentamicin-loaded CaS-HA biocomposite, arthrodesis with Kirschner wire. }\end{array}$ & $2(3)$ \\
\hline $\begin{array}{l}\text { Osteotomy of metatarsal(s), debridement of medullary canal(s), filling with } \\
\text { gentamicin-loaded CaS-HA biocomposite. }\end{array}$ & $10(16)$ \\
\hline
\end{tabular}


Table A1. Cont.

\begin{tabular}{|c|c|}
\hline Surgical Procedures & No. $(\%)$ \\
\hline $\begin{array}{l}\text { Amputation of metatarsal head(s), debridement of medullary canal(s) and } \\
\text { filling with gentamicin-loaded CaS-HA biocomposite. }\end{array}$ & $8(13)$ \\
\hline $\begin{array}{l}\text { Arthrotomy of tarsometatarsal joint(s), resection of joint with distal part of } \\
\text { one or multiple tarsals and base of one or multiple metatarsals, dead space } \\
\text { filling with gentamicin-loaded CaS-HA biocomposite. }\end{array}$ & $8(13)$ \\
\hline $\begin{array}{l}\text { Arthrotomy of tarsometatarsal joint(s), resection with distal part of tarsal(s) } \\
\text { and base of metatarsal(s), dead space filling with gentamicin-loaded } \\
\text { CaS-HA biocomposite, temporary external fixation. }\end{array}$ & $1(2)$ \\
\hline $\begin{array}{l}\text { Arthrotomy of tarsometatarsal joint(s), resection with distal part of tarsal(s) } \\
\text { and base of metatarsal(s), dead space filling with gentamicin-loaded } \\
\text { CaS-HA biocomposite, internal screw fixation. }\end{array}$ & $1(2)$ \\
\hline $\begin{array}{l}\text { Partial or complete extirpation of tarsal(s), dead space filling with } \\
\text { gentamicin-loaded CaS-HA biocomposite. }\end{array}$ & $1(2)$ \\
\hline $\begin{array}{l}\text { Partial or complete extirpation of tarsal(s), dead space filling with } \\
\text { gentamicin-loaded CaS-HA biocomposite, temporary external fixation }\end{array}$ & $2(3)$ \\
\hline $\begin{array}{l}\text { Partial or complete extirpation of tarsal(s), dead space filling with } \\
\text { gentamicin-loaded CaS-HA biocomposite, internal screw fixation. }\end{array}$ & $1(2)$ \\
\hline $\begin{array}{l}\text { Partial calcanectomy, surgical debridement and dead space filling with } \\
\text { gentamicin-loaded CaS-HA biocomposite. }\end{array}$ & $4(6)$ \\
\hline $\begin{array}{l}\text { Partial calcanectomy, drilling of multiple tunnels in the calcaneum, filling } \\
\text { with gentamicin-loaded CaS-HA biocomposite ("silo technique") [24]. }\end{array}$ & $3(5)$ \\
\hline Treatment Characteristics & No. $(\%)$ \\
\hline Volume of gentamicin-loaded CaS-HA biocomposite used (mL). & $5(4-5)$ \\
\hline \multicolumn{2}{|l|}{ Form of gentamicin-loaded CaS-HA biocomposite used } \\
\hline - $\quad$ Fluid phase & $59(92)$ \\
\hline - $\quad$ Solid phase (e.g., pellets) & $5(8)$ \\
\hline Use of pressure tourniquet during surgical procedure. & $21(33)$ \\
\hline \multicolumn{2}{|l|}{ Method of surgical wound closure } \\
\hline Primary closure & $57(89)$ \\
\hline - $\quad$ Local transposition & $6(9)$ \\
\hline Regional tissue transposition & $1(2)$ \\
\hline \multicolumn{2}{|l|}{ Perioperative antibiotic therapy } \\
\hline - $\quad$ None & $32(50)$ \\
\hline - $\quad$ Carbapenems & $1(3)$ \\
\hline - $\quad$ Cephalosporins & $7(23)$ \\
\hline - $\quad$ Cephalosporins + trimethoprim/sulfamethoxazole & $1(3)$ \\
\hline
\end{tabular}


Table A1. Cont.

\begin{tabular}{|c|c|}
\hline Surgical Procedures & No. (\%) \\
\hline - $\quad$ Cephalosporins + fluoroquinolones & $1(3)$ \\
\hline - $\quad$ Cephalosporins + macrolides & $2(6)$ \\
\hline - $\quad$ Cephalosporins + metronidazole & $1(3)$ \\
\hline - $\quad$ Fluoroquinolones + macrolides & $5(16)$ \\
\hline Penicillins & $11(34)$ \\
\hline Penicillins + fluoroquinolones & $1(3)$ \\
\hline Trimethoprim/sulfamethoxazole41 & $1(3)$ \\
\hline Vancomycin & $1(3)$ \\
\hline \multicolumn{2}{|c|}{ Route of administration of perioperative antibiotic therapy } \\
\hline - $\quad$ Oral & $6(9)$ \\
\hline Parenteral & $26(41)$ \\
\hline \multicolumn{2}{|l|}{ Method of anaesthesia } \\
\hline - $\quad$ General & $18(28)$ \\
\hline - $\quad$ Spinal & $15(24)$ \\
\hline - $\quad$ Regional & $29(45)$ \\
\hline - $\quad$ Local & $2(3)$ \\
\hline Duration of surgery (minutes) & $46 \pm 21$ \\
\hline
\end{tabular}

\section{References}

1. Armstrong, D.G.; Boulton, A.J.M.; Bus, S.A. Diabetic Foot Ulcers and Their Recurrence. N. Engl. J. Med. 2017, 376, 2367-2375. [CrossRef]

2. Zhang, Y.; Lazzarini, P.A.; McPhail, S.M.; van Netten, J.J.; Armstrong, D.G.; Pacella, R.E. Global Disability Burdens of DiabetesRelated Lower-Extremity Complications in 1990 and 2016. Diabetes Care 2020, 43, 964-974. [CrossRef]

3. Prompers, L.; Huijberts, M.; Apelqvist, J.; Jude, E.; Piagessi, A.; Bakker, K.; Edmonds, M.; Holstein, P.; Jirkovska, A.; Mauricio, D.; et al. High prevalence of ischaemia, infection and serious comorbidity in patients with diabetic foot disease in Europe. Baseline results from the Eurodiale study. Diabetologia 2007, 50, 18-25. [CrossRef]

4. Jia, L.; Parker, C.N.; Parker, T.J.; Kinnear, E.M.; Derhy, P.H.; Alvarado, A.M.; Huygens, F.; Lazzarini, P.A. Incidence and risk factors for developing infection in patients presenting with uninfected diabetic foot ulcers. PLoS ONE 2017, 12, e0177916. [CrossRef] [PubMed]

5. Raspovic, K.M.; Wukich, D.K. Self-reported quality of life and diabetic foot infections. J. Foot Ankle Surg. 2014, 53, 716-719. [CrossRef] [PubMed]

6. Hicks, C.W.; Selvarajah, S.; Mathioudakis, N.; Sherman, R.E.; Hines, K.F.; Black, J.H., III; Abularrage, C.J. Burden of Infected Diabetic Foot Ulcers on Hospital Admissions and Costs. Ann. Vasc. Surg. 2016, 33, 149-158. [CrossRef] [PubMed] 
7. Lavery, L.A.; Armstrong, D.G.; Peters, E.J.G.; Lipsky, B.A. Probe-to-bone test for diagnosing diabetic foot osteomyelitis: Reliable or relic? Diabetes Care 2007 30, 270-274. [CrossRef]

8. Van Netten, J.J.; Bus, S.A.; Apelqvist, J.; Lipsky, B.A.; Hinchliffe, R.J.; Game, F.L.; Rayman, G.; Lazzarini, P.A.; Forsythe, R.O.; Peters, E.J.G.; et al. Definitions and criteria for diabetic foot disease. Diabetes Metab. Res. Rev. 2020, 36, e3268. [CrossRef] [PubMed]

9. Lipsky, B.A.; Itani, K.; Norden, C. Treating foot infections in diabetic patients: A randomized, multicenter, open-label trial of linezolid versus ampicillin-sulbactam/amoxicillin-clavulanate. Clin. Infect. Dis. 2004, 38, 17-24. [CrossRef]

10. Mutluoglu, M.; Sivrioglu, A.K.; Eroglu, M.; Uzun, G.; Turhan, V.; Ay, H.; Lipsky, B.A. The implications of the presence of osteomyelitis on outcomes of infected diabetic foot wounds. Scand. J. Infect. Dis. 2013, 45, 497-503. [CrossRef]

11. Gurlek, A.; Bayraktar, M.; Savas, C.; Gedik, O. Amputation rate in 147 Turkish patients with diabetic foot: The Hacettepe University Hospital experience. Exp. Clin. Endocrinol. Diabetes 1998, 106, 404-409. [CrossRef] [PubMed]

12. Hartemann-Heurtier, A.; Senneville, E. Diabetic foot osteomyelitis. Diabetes Metab. 2008, 34, 87-95. [CrossRef] [PubMed]

13. Schaper, N.C.; van Netten, J.J.; Apelqvist, J.; Bus, S.A.; Hinchliffe, R.J.; Lipsky, B.A. Practical Guidelines on the prevention and management of diabetic foot disease (IWGDF 2019 update). Diabetes Metab. Res. Rev. 2020, 36 (Suppl. 1), e3266. [CrossRef] [PubMed]

14. Lipsky, B.A.; Senneville, E.; Abbas, Z.G.; Aragón-Sánchez, F.J.; Diggle, M.; Embil, J.M.; Kono, S.; Lavery, L.A.; Malone, M.; van Asten, S.A.; et al. Guidelines on the diagnosis and treatment of foot infection in persons with diabetes (IWGDF 2019 update). Diabetes Metab. Res. Rev. 2020, 36 (Suppl. 1), e3280. [CrossRef]

15. Jeffcoate, W.J.; Bus, S.A.; Game, F.L.; Hinchliffe, R.J.; Price, P.E.; Schaper, N.C. Reporting standards of studies and papers on the prevention and management of foot ulcers in diabetes: Required details and markers of good quality. Lancet Diabetes Endocrinol. 2016, 4, 781-788. [CrossRef]

16. Ha Van, G.; Siney, H.; Danan, J.P.; Sachon, C.; Grimaldi, A. Treatment of osteomyelitis in the diabetic foot. Contribution of conservative surgery. Diabetes Care 1996, 19, 1257-1260. [CrossRef]

17. Aragón-Sánchez, F.J.; Cabrera-Galván, J.J.; Quintana-Marrero, Y.; Hernández-Herrero, M.J.; Lázaro-Martínez, J.L.; García-Morales, E.; Beneit-Montesinos, J.V.; Armstrong, D.G. Outcomes of surgical treatment of diabetic foot osteomyelitis: A series of 185 patients with histopathological confirmation of bone involvement. Diabetologia 2008, 51, 1962-1970. [CrossRef]

18. Aragón-Sánchez, F.J.; Lázaro-Martínez, J.L.; Hernández-Herrero, C.; Campillo-Villorio, N.; Quintana-Marrero, Y.; García-Morales, E.; Hernández-Herrero, M.J. Does osteomyelitis in the feet of patients with diabetes really recur after surgical treatment? Natural history of a surgical series. Diabet. Med. 2012, 29, 813-818. [CrossRef]

19. Henke, P.K.; Blackburn, S.A.; Wainess, R.W.; Cowan, J.; Terando, A.; Proctor, M.; Wakefield, T.W.; Upchurch, G.R., Jr.; Stanley, J.C.; Greenfield, L.J. Osteomyelitis of the foot and toe in adults is a surgical disease: Conservative management worsens lower extremity salvage. Ann. Surg. 2005, 241, 884-885. [CrossRef]

20. Nilsson, M.; Zheng, M.H.; Tägil, M. The composite of hydroxyapatite and calcium sulphate: A review of preclinical evaluation and clinical applications. Expert Rev. Med. Devices 2013, 10, 675-684. [CrossRef]

21. Markakis, K.; Faris, A.R.; Sharaf, H.; Faris, B.; Rees, S.; Bowling, F.L. Local Antibiotic Delivery Systems: Current and Future Applications for Diabetic Foot Infections. Int. J. Low Extrem. Wounds 2018, 17, 14-21. [CrossRef] [PubMed]

22. McNally, M.A.; Ferguson, J.Y.; Lau, A.C.K.; Diefenbeck, M.; Scarborough, M.; Ramsden, A.J.; Atkins, B.L. Single-stage treatment of chronic osteomyelitis with a new absorbable, gentamicin-loaded, calcium sulphate/ hydroxyapatite biocomposite. Bone Jt. J. 2016, 98B, 1289-1296. [CrossRef] [PubMed]

23. Niazi, N.S.; Drampalos, E.; Morrissey, N.; Jahangir, N.; Wee, A.; Pillai, A. Adjuvant antibiotic loaded bio composite in the management of diabetic foot osteomyelitis-A multicentre study. Foot 2019, 39, 22-27. [CrossRef] [PubMed]

24. Drampalos, E.; Mohammad, H.R.; Kosmidis, C.; Balal, M.; Wong, J.; Pillai, A. Single stage treatment of diabetic calcaneal osteomyelitis with an absorbable gentamicin-loaded calcium sulphate/hydroxyapatite biocomposite: The Silo technique. Foot 2018, 34, 40-44. [CrossRef] [PubMed]

25. Stravinskas, M.; Horstmann, P.; Ferguson, J.; Hettwer, W.; Nilsson, M.; Tarasevicius, S.; Petersen, M.M.; McNally, M.A.; Lidgren, L. Pharmacokinetics of gentamicin eluted from a regenerating bone graft substitute: In vitro and clinical release studies. Bone Jt. Res. 2016, 5, 427-435. [CrossRef]

26. Colding-Rasmussen, T.; Horstmann, P.; Petersen, M.M.; Hettwer, W. Antibiotic Elution Characteristics and Pharmacokinetics of Gentamicin and Vancomycin from a Mineral Antibiotic Carrier: An in vivo Evaluation of 32 Clinical Cases. J. Bone Jt. Infect. 2018, 3, 234-240. [CrossRef]

27. Nilsson, M.; Wang, J.S.; Wielanek, L.; Tanner, K.E.; Lidgren, L. Biodegradation and biocompatability of a calcium sulphatehydroxyapatite bone substitute. J. Bone Jt. Surg. Br. 2004, 86, 120-125. [CrossRef]

28. Hutting, K.H.; van Netten, J.J.; Dening, J.; ten Cate, W.A.; van Baal, J.G. Surgical debridement and gentamicin-loaded calcium sulphate/hydroxyapatite bone void filling to treat diabetic foot osteomyelitis. Diabet. Foot J. 2019, 22, $22-27$.

29. Whisstock, C.; Volpe, A.; Ninkovic, S.; Marin, M.; Meloni, M.; Bruseghin, M.; Boschetti, G.; Brocco, E. Multidisciplinary Approach for the Management and Treatment of Diabetic Foot Infections with a Resorbable, Gentamicin-Loaded Bone Graft Substitute. J. Clin. Med. 2020, 9, 3586. [CrossRef]

30. Richtlijnen Database. Richtlijn Diabetische Voet. Available online: https://richtlijnendatabase.nl/richtlijn/diabetische_voet/ startpagina_diabetische_voet.html (accessed on 1 April 2020). 
31. NICE. NICE Guideline [NG19]: Diabetic Foot Problems: Prevention and Management. Available online: https:/ /www.nice.org. uk/guidance/ng19/chapter/Recommendations\#diabetic-foot-infection (accessed on 1 April 2020).

32. Senneville, E.M.; Lipsky, B.A.; van Asten, S.A.V.; Peters, E.J. Diagnosing diabetic foot osteomyelitis. Diabetes Metab. Res. Rev. 2020, 36 (Suppl. 1), e3250. [CrossRef]

33. Mills, J.L.S.; Conte, M.S.; Armstrong, D.G.; Pomposelli, F.B.; Schanzer, A.; Sidawy, A.N.; Andros, G. The Society for Vascular Surgery Lower Extremity Threatened Limb Classification System: Risk stratification based on wound, ischemia, and foot infection (WIfI). J. Vasc. Surg. 2014, 59, 220-222. [CrossRef] [PubMed]

34. Ince, P.; Abbas, Z.G.; Lutale, J.K.; Basit, A.; Chohan, F.; Morbach, S.; Möllenberg, J.; Game, F.L.; Jeffcote, W.J. Use of the SINBAD Classification System and Score in Comparing Outcome of Foot Ulcer Management on Three Continents. Diabetes Care 2008, 31, 964-967. [CrossRef] [PubMed]

35. Bus, S.A.; Waaijman, R.; Arts, M.; de Haart, M.; Busch-Westbroek, T.; van Baal, J.G.; Nollet, F. Effect of custom-made footwear on foot ulcer recurrence in diabetes: A multicenter randomized controlled trial. Diabetes Care 2013, 36, 4109-4116. [CrossRef] [PubMed]

36. European Committee on Antimicrobial Susceptibility Testing. Breakpoint Tables for Interpretation of MICs and Zone Diameters. Version 9.0. 2019. Available online: https://www.eucast.org/fileadmin/src/media/PDFs/EUCAST_files/Breakpoint_tables/v_ 9.0_Breakpoint_Tables.pdf (accessed on 1 December 2019).

37. Whiting, P.F.; Rutjes, A.W.S.; Westwood, M.E.; Mallett, S.; Deeks, J.J.; Reitsma, J.B.; Leeflang, M.M.G.; Sterne, J.A.C.; Bossuyt, P.M.M. QUADAS-2: A revised tool for the quality assessment of diagnostic accuracy studies. Ann. Intern. Med. 2011, 155, 529-536. [CrossRef] [PubMed]

38. Faglia, E.; Clerici, G.; Caminiti, M.; Curci, V.; Somalvico, F. Influence of osteomyelitis location in the foot of diabetic patients with transtibial amputation. Foot Ankle Int. 2013, 34, 222-227. [CrossRef] [PubMed]

39. Bus, S.A.; Valk, G.D.; van Deursen, R.W.; Armstrong, D.G.; Caravaggi, C.; Hlaváček, P.; Bakker, K.; Cavanagh, P.R. The effectiveness of footwear and offloading interventions to prevent and heal foot ulcers and reduce plantar pressure in diabetes: A systematic review. Diabetes Metab. Res. Rev. 2008, 24 (Suppl. 1), S162-S180. [CrossRef] [PubMed]

40. Ince, P.; Kendrick, D.; Game, F.; Jeffcoate, W. The association between baseline characteristics and the outcome of foot lesions in a UK population with diabetes. Diabet. Med. 2007, 24, 977-981. [CrossRef]

41. Bus, S.A.; Armstrong, D.G.; Gooday, C.; Jarl, G.; Caravaggi, C.; Viswanathan, V.; Lazzarini, P.A. Guidelines on offloading foot ulcers in persons with diabetes (IWGDF 2019 update). Diabetes Metab. Res. Rev. 2020, 36 (Suppl. 1), e3274. [CrossRef] [PubMed] 